\title{
Computerization of Local Language Characters
}

\section{An Innovative Model for Language Maintenance in South Sulawesi, Indonesia}

\author{
Yusring Sanusi Baso ${ }^{1}$ \\ Center for Media \\ Learning Resources and E-Learning \\ Quality Assurance and Education Development Institutions \\ Hasanuddin University, Makassar, Indonesia 90245
}

\author{
Andi Agussalim ${ }^{2}$ \\ Laboratory of Educational Technology \\ Department of Western Asian Languages \\ Faculty of Cultural Science, Hasanuddin University \\ Makassar, Indonesia 90245
}

\begin{abstract}
The objective of this study is to provide innovative model for the approach of language preservation. It is necessary to maintain indigenous languages in order to avoid language death. Script applications for indigenous languages are one of the solutions being pursued. This script program will facilitate communication through writing between speakers of indigenous languages. Additionally, the study illustrates the implementation of the Lontara script (Bugis-Makassar local language letters and characters). This script application is compatible with the Microsoft Windows operating system and the Hypertext Transfer Protocol (HTTP). This study employed the research and development (R\&D) approach. Six stages are followed in this $R$ \& D study: 1) doing a requirements analysis to determine the viability of Bugis-Makassar indigenous languages in everyday life and also to determine ways to retain them 2) designing and constructing Lontara scripts with hypertext-based applications, 3) producing Lontara scripts with hypertext-based applications, and 4) validating the hypertext-based applications through oneto-one testing, small and large group testing. 5) Lontara application revision; and 6) Lontara application as a finished product. This product is designed to be used in conjunction with other interactive applications.
\end{abstract}

Keywords-Innovative model; language maintenance; Lontara script; Makassarese; local language; hypertext-based application

\section{INTRODUCTION}

Indonesia is a multi-ethnic and multilingual country. The Indonesian Central Bureau of Statistics [1] revealed that Indonesia consists of 1,128 ethnic groups. Besides, BPS also presents ethnographic data and records about 700 local languages owned by Indonesia's state. The diversity of ethnic groups in Indonesia is caused by various factors, including historical and natural isolation factors. The old nature isolation factor also influences Indonesia's condition, which various ethnic groups inhabit. Therefore, ethnics are diverse and have their characteristics in terms of language and culture, although they all belong to the same language family, the Austronesian. On the other hand, there are 7,117 languages in the world that are spoken today, and it has estimated in the year 2020 that 40$90 \%$ of them will disappear during this century [2]. However, $20-50 \%$ of this amount is no longer used by the younger generation of its native [3].

The picture of the vitality of local languages in Indonesia, in South Sulawesi, is still unclear. It is still challenging to obtain accurate data on local language vitality in South Sulawesi. However, this condition can be seen by a glance at native speakers of Makassarese, one of the local languages in South Sulawesi. The vitality of the Makassar language can be seen by the Extended Graded Intergenerational Disruption Scale (EGIDS) rubric that has been developed by Simons and Lewis [4] and [5]. Based on EGIDS, the Makassar language is at level $6 b$ [6], [7].

The vitality of local Indonesian languages is more easily recognized by the EGIDS than other scales, for example, the Fisman scale [8]. Fishman's Graded Intergenerational Disruption Scale (GIDS) and UNESCO's five steps endangerment framework. EGIDS is a union of the Fishman scale and the UNESCO scale. The EGIDS scale can be seen as in the following Table I.

Based on EGIDS, we can assess the vitality of the Makassar language. However, before assessing its vitality, we should first understand the local language environment in Indonesia. Indonesia's local language environment is the pressure most like in China, both vertical and horizontal pressure [9]. The pressure on Indonesia's local languages generally comes from Indonesian and its dominant or more native languages. This pressure is due to prestige for Indonesian speakers, educational interests, and even economic factors. Another is the Indonesian language pressure, which comes from international languages, Arabic and English.

On the other hand, regional languages are under the position of Indonesian. Therefore, horizontal pressure can occur from other regional languages with a better sociolinguistic status [10]. This condition further weakens the vitality of local languages in Indonesia.

Ethologically, this condition can be understood that Indonesia's local languages are very worrying [4], [11], [12].

Based on the above Table II, it can be seen that almost half of Indonesia's languages are "in trouble or worse." The number of languages that are rated "Vigorous" (260) compared with those that are "In trouble" (272) can be concluded that the local languages in Indonesia are in trouble. We can also have an alternate assessment and visual representation to obtain local language vitality in Indonesia through UNESCO"s. "Interactive Atlas of the World's Languages in Danger" classifies 144 of Indonesia's languages as "Vulnerable" or worse. Ethnologue website has stated that:

"The number of individual languages listed for Indonesia is 719. Of these, 707 are living, and 12 are extinct. Of the living 
languages, 701 are indigenous, and six are non-indigenous. Furthermore, 18 are institutional, 81 are developing, 260 are vigorous, 272 are in trouble, and 76 are dying [13].

Based on this fact, the research question is, "How to design an innovative model of local language maintenance?"

TABLE I. EXPANDED GRADED INTERGENERATIONAL DISRUPTION SCALE

\begin{tabular}{|c|c|c|c|}
\hline Level & Label & Description & UNESCO \\
\hline 0 & International & $\begin{array}{l}\text { The language is used internationally } \\
\text { for a broad range of functions. }\end{array}$ & Safe \\
\hline 1 & National & $\begin{array}{l}\text { The language is used in education, } \\
\text { work, mass media, government at the } \\
\text { national level. }\end{array}$ & Safe \\
\hline 2 & Regional & $\begin{array}{l}\text { The language is used for local and } \\
\text { regional mass media and } \\
\text { governmental services. }\end{array}$ & Safe \\
\hline 3 & Trade & $\begin{array}{l}\text { The language is used for local and } \\
\text { regional work by both insiders and } \\
\text { outsiders. }\end{array}$ & Safe \\
\hline 4 & Educational & $\begin{array}{l}\text { Literacy in the language is being } \\
\text { transmitted through a system of public } \\
\text { education. }\end{array}$ & Safe \\
\hline 5 & Developing & $\begin{array}{l}\text { The language is used orally by all } \\
\text { generations and is effectively used in } \\
\text { written form in parts of the } \\
\text { community. }\end{array}$ & Safe \\
\hline $6 a$ & Vigorous & $\begin{array}{l}\text { The language is used orally by all } \\
\text { generations and is being learned by } \\
\text { children as their first language. }\end{array}$ & Safe \\
\hline $6 b$ & Threatened & $\begin{array}{l}\text { The language is used orally by all } \\
\text { generations, but only some child- } \\
\text { bearing generation transmit it to their } \\
\text { children. }\end{array}$ & Vulnerable \\
\hline 7 & Shifting & $\begin{array}{l}\text { The child-bearing generation knows } \\
\text { the language well enough to use it } \\
\text { among themselves, but none are } \\
\text { transmitting it to their children }\end{array}$ & $\begin{array}{l}\text { Definitely } \\
\text { endangered }\end{array}$ \\
\hline $8 a$ & Moribund & $\begin{array}{l}\text { The only remaining active speakers of } \\
\text { the language are members of the } \\
\text { grandparent generation. }\end{array}$ & $\begin{array}{l}\text { Severely } \\
\text { endangered }\end{array}$ \\
\hline $8 b$ & $\begin{array}{l}\text { Nearly } \\
\text { Extinct }\end{array}$ & $\begin{array}{l}\text { The only remaining speakers of the } \\
\text { language are members of the } \\
\text { grandparent generation or older who } \\
\text { have little opportunity to use the } \\
\text { language. }\end{array}$ & $\begin{array}{l}\text { Critically } \\
\text { endangered }\end{array}$ \\
\hline 9 & Dormant & $\begin{array}{l}\text { The language serves as a reminder of } \\
\text { heritage identity for an ethnic } \\
\text { community. No one has more than } \\
\text { symbolic proficiency. }\end{array}$ & Extinct \\
\hline 10 & Extinct & $\begin{array}{l}\text { No one retains a sense of ethnic } \\
\text { identity associated with the language, } \\
\text { even for symbolic purposes. }\end{array}$ & Extinct \\
\hline
\end{tabular}

TABLE II. EGIDS OVERVIEW OF THE VITALITY OF LANGUAGES OF INDONESIA

\begin{tabular}{|c|c|c|c|c|c|c|}
\hline \multirow{2}{*}{$\begin{array}{l}\text { Langua } \\
\text { ges }\end{array}$} & \multirow{2}{*}{$\begin{array}{l}\text { Institutio } \\
\text { nal } \\
\text { (EGIDS } \\
1-4)\end{array}$} & \multirow{2}{*}{$\begin{array}{l}\text { Developi } \\
\text { ng } \\
\text { (EGIDS } \\
\text { 5) }\end{array}$} & \multirow{2}{*}{$\begin{array}{l}\text { Vigoro } \\
\text { us } \\
\text { (EGID } \\
\text { S 6a) }\end{array}$} & $\begin{array}{l}\text { Threaten } \\
\text { ed }\end{array}$ & Dying & $\begin{array}{l}\text { Extinc } \\
t\end{array}$ \\
\hline & & & & $\begin{array}{l}\text { (EGIDS } \\
6 b-7)\end{array}$ & $\begin{array}{l}\text { (EGI } \\
\text { DS } \\
8 \mathrm{8}-9)\end{array}$ & $\begin{array}{l}\text { (EGI } \\
\text { DS } \\
10) \\
\end{array}$ \\
\hline 719 & 18 & 81 & 260 & 272 & 76 & 12 \\
\hline
\end{tabular}

\section{RELATED WORK}

Language maintenance programs, language shift, and endangered language are topics that have never-ending debate. The linguists are always looking for alternative plans to maintain minority languages that a language shift has caused. Language researchers often face people who leave their mother tongue due to political and economic pressures [14][16]. A language preservation program is carried out in legal recognition of the minority language [17], [18]. Other researchers propose a theory for heritage language, literacy, and identity processes to maintain minority languages [19]. Other language researchers make breakthroughs in maintaining minority languages by using a smartphone [20].

Other studies have shown that sometimes a language appears suddenly, spreads quickly, and quickly disappear. This case challenges linguists to document, describe, preserve, and revitalize languages [21], [22]. Another linguistic phenomenon that often affects decreasing local language speakers is the influence of strong language used on daily life, both informal and non-formal [10]. Preservation of minority languages can survive because it is a language preservation policy [23].

In his book on global paradox, John Naisbitt reiterated that globalization promotes a paradoxical tendency [24]. John Naisbitt's view is proven at present. Technological advances in transformation and the informatics revolution have led to human beings' tendency to a one-tier, modern, and global world. On the other hand, modern humans also long for past histories in ethnic romance, values, and primordial styles. The point of these tendencies can cause conflict, friction, and shock.

If John Naisbitt's view is compiled with ethnological data, modern world-class and ethnic romance and primordial values are inevitable. Our society is undoubtedly inseparable from cyberspace and connectivity that can no longer be encountered. At the same time, the use of local languages is decreasing. The shortcomings can be seen in the number of websites or sites that provide local language information.

The clash of these trends creates implications for the use of local languages. The local language users are more likely to use Indonesian as their daily language. This condition cannot be avoided because Indonesian is the national and official language, both oral and written. It is understandable if people use Indonesian to communicate daily, both at work and sharing information. The local language is only used at the oral or spoken level and rarely uses local language in written form.

The shift in language utilization from the local to the Indonesian language is caused by various factors, including economic factors, migration, and marriage. Economic factors caused Makassar speakers (for example) in Gowa Regency's highlands to use the Indonesian language. Javanese speakers and other tribes who trade in this area use the Indonesian language. The influence is quite crucial, which appears from the public began to get used to speaking Indonesian. On the other hand, the Indonesian language is considered prestigious and proud of society's expression when using the Indonesian language. When we as researchers met Ngawing, one of an elder in this village, he said in Makassarese that "abbicara 
malayu tauwwa," which means "Wow, they speak Indonesian." This sentence is an expression of those who can speak Indonesian [25]. The Indonesian language is forced to be used as a communication language in the commerce sector. Although it unwittingly has shifted the attitude of the language of some highland communities of Gowa Regency, especially in the Tompobulu district, this condition is very reasonable.

Population migration to Makassar City is another factor that contributing to the shift of language use from Makassar to the Indonesian language. Some Gowa highland residents in Tompobulu Sub-district moved to Makassar city looking for work after harvesting in the dry season. Young people in their productive ages left home to earn a living. Some of them migrated to the island of Borneo and the country of Malaysia. When returning to the village or returning home, they generally use the Indonesian and Malay languages. Not infrequently among them "back home" to meet their relatives and back again to the island of Borneo and the State of Malaysia. They prefer to speak Indonesian or Malay rather than Makassar [25].

Inter-tribal marriage also became the cause of the shift of language use from Makassar to Indonesian. Some Gowa highlands residents have been married to other tribes like Bugis, Mandar, Toraja, and Java. Families who are married to other tribes use Indonesian in their daily conversation. Makassar language is used only if their relatives who use it visit them, but when other relatives visit them from mixedmarriage status, they use Indonesian.

Shifting the use of language from this local language to the Makassar language needs to be addressed. If the shift has taken place at the oral language level, it can be expected that the use of local languages in writing may be more severe. More severe in the sense that as majority speakers of local languages, in this case, speakers of Makassar, they no longer use the language of Makassar in writing. This condition is worsened by the digital era that does not provide characters or lontara letters required in various applications, for example, on the hypertext level or the website page.

Various attempts at writing Lontara script have been made, including typewriters, machine-set photos, and computers. The recording of Lontara script making was once presented by Barbara Friberg [26] at a Makassar Golden Hotel seminar. Barbara is evident in the exposition of the history of the digitization development of the Lontara script.

In 1985, the Consulate General of Japan in Makassar sponsored the manufacture of the Lontara typewriter. This device is good enough, and it can produce a good letter. However, typewriters have some weaknesses, including the letters' size is small and the same width. This size results in less than perfect spaces. Whatever the outcome, Taufik Sakuma's efforts should be rewarded for speakers of languages that use the Lontara script [26].

Five years following, in 1990, at Language Center in Ujung Pandang, Ms. Astuti Hendrato from Jakarta collaborated with Monotype Typography in England and worked on Lontara script using LASERCOMP the photo-set machine. A year later, in 1991, USI / IBM, for the guidance of the former Rector of Hasanuddin University and South Sulawesi Governor, Prof. Dr. Ahmad Amiruddin, and Makasar community leaders, provided a computer with a scanner to preserve the Lontara texts. As a result, the manuscripts can be stored on a computer that can then be published quickly. This effort means preserving the Lontara manuscripts in the file image form on the computer. Thus, the systems (font/font types, such as TrueType Font types compatible with Windows) used to write computer-assisted Lontara scripts did not exist yet [26].

Barbara Friberg has also done a person who works on writing Lontara script. She once applied to Monotype Typography in the United Kingdom to help the Makasar community acquire fonts-computers that can be used in various personal computers, not just on specific machines. In 1991, Barbara Friberg's colleague in Singapore was willing to help prepare the Lontara font used on similar IBM-PC and Microsoft Word programs. With the help of Drs. Djirong Basang, Barbara Friberg sent a picture for every Lontara letter used in the Makasar language. The effort was running, but eventually, Barbara Friber's colleague in Singapore could not complete making the Lontara font as expected. In 1994, Barbara Friberg then tried to build the Lontara script font. She continued to develop the program, which was not finished in Singapore. The program that Barbara Friberg used to build the font was the FONTMONGER program. With this program, she created a Lontar21 font with type, True-Type, later known as Lontar21.ttf. The file size is $28 \mathrm{~kb}$. This font was presented in Makassar Golden Hotel in October 1995 [25].

In the same year, precisely in December 1995, Andi Mallarangeng and Jim Henry made Lontara font volume one with BugisA (also with True Type type). BugisA.ttf font file size is $16 \mathrm{~kb}$. However, BugisA font is often experiencing constraints or unstable in Office Word (Windows). An example of a common obstacle is that the Lontara script's initial letters often turn into Latin or boxes in the first word in each paragraph's first sentence. The two types of fonts, both Lontar21 and BugisA fonts, do not add specific numbers to Lontara. Both types of fonts can only be run and used on Windows-based operating systems. Both of these fonts also cannot be used in hypertext-based platforms. In other words, both types of fonts cannot be used to write messages in emails (email) and social media Facebook. The two fonts are also not prepared a consonant marker (diacritic) to facilitate Lontara character speakers reading the Lontara script. Thus, this hypertext-based Lontara font is a development of the previous font.

The character development history triggers the addition of numeric characters and consonant markers to the Lontara script application. The researchers found it essential to add the character of numbers and consonant markers in the Lontara script after seeing the Hijaiyah script's development (Arabic). At first, the Arabic script did not recognize a point and was without a vowel. The example of letters that do not have dots are $[\ulcorner],[\tau]$, and $[\dot{\tau}]$. These three letters are the same; both have no dots in the form [ح]. It is similar to the other letters,

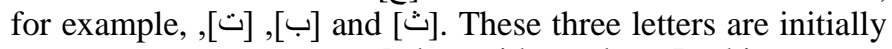
in the same form, i.e., [ب], but without dots. In this era, not many people can read and write in Arabic script. 
History records the development of Arabic script mastery through the punishment for prisoners of the Badr war. After the war, the Muslims captured the Quraysh army. Umar bin Khattab r.a asked that they should be beheaded. However, Abu Bakr r.a. disagreed and proposed that the ransom of literate prisoners teach ten Muslims' sons. As for those who cannot read and write, redeemed in the form of payment. Both ransoms are indispensable for the Muslims at that time.

At the time of Ali bin Abi Talib came the scholar Abu alAs'ad al-Du'ali [27], who added dots to the Arabic character. Furthermore, the addition of marking (harakat) or the line is done by other scholars, namely Ahmad al-Khalil [28]. The addition of this vowel made it easier for non-Arabic speakers to read the Qur'an and hadith correctly. However, for educated and able to read Arabic script without a vowel, the additional marking is no longer needed. Therefore, the Hijaiyah script's development is the idea that inspires writers to add Lontara characters, numbers, and consonant markers.

It should be noted that the Lontara script is syllable and has no consonants. This condition makes a word written in the Lontara script sometimes difficult to read, not only by foreign speakers of the Makassar language but also the native speakers. The word "paja" /paja/ can be read /paja/ which means butt and can also be read /pa'ja/ which means salty. This condition is like an Arabic character with no marking (harakat) and can be read according to the position of words in a sentence. This condition has inspired the research team to modify or additions to the characters in the Lontara script.

\section{METHODOLOGY}

This study uses research and development (R \& D) methods [29]-[31]. According to Borg and Gall, "R \& D method is a process used to develop and validate educational products." Therefore, this sentence can be interpreted that the $\mathrm{R}$ \& $\mathrm{D}$ method is developing and validating educational products. Thus, R \& D has a series of cyclical research and development steps. Additionally, each step to be performed should refer to the results of the previous step. Therefore, a new educational product will be obtained at the end of every stage or step applied.

Borg and Gall have presented a series of stages to be followed in this R \& D approach: research and information collecting, planning, preliminary proof of form, preliminary field testing, primary product revision, main field testing, operational product revision, operational field testing, final product revision and dissemination and implementation.

R \& D research stages, both discovered by Borg and Gall and by Dick and Careys, have ten steps. Of course, this stage of the $\mathrm{R} \& \mathrm{D}$ model always culminates with a product or output. However, in this research, R \& D steps are modified in such a way as required. According to the end of the research stage, the researchers determine that other researchers can continue these steps. Whatever stage is chosen at the end of the research stage, the result remains a product.

Research development of Lontara script application with this hypertext-based ends at the sixth step called the final product. The following are the steps:
- Needs analysis. The researchers have conducted a needs analysis and literature review.

- Design of the lontara character application. In this step, the researchers designed a model of the lontara script application. Again, the researchers focused on software, hardware, and humanware characteristics.

- Development of the lontara script application. By this step, the researchers have developed true type font for windows and a lontara character application for HTML called Yusring Keyboard.

- Formative evaluation step. This formative evaluation stage consists of expert validation, one-to-one testing, small group testing, and large group testing. In addition, participants who participated in this stage filled out an instrument called the Technology Acceptance Model (TAM).

- Revision of the lontara character application. Based on the instrument from participants, researchers revised bugs that occur during the stage of formative evaluation.

- Final Product. Thus, this application (yusring keyboard) has been tested in the small and large groups test phase of Formative Evaluation or the fourth stage. The yusring keyboard is ready to use.

In brief, the stages of this method can be seen in the following Fig. 1:

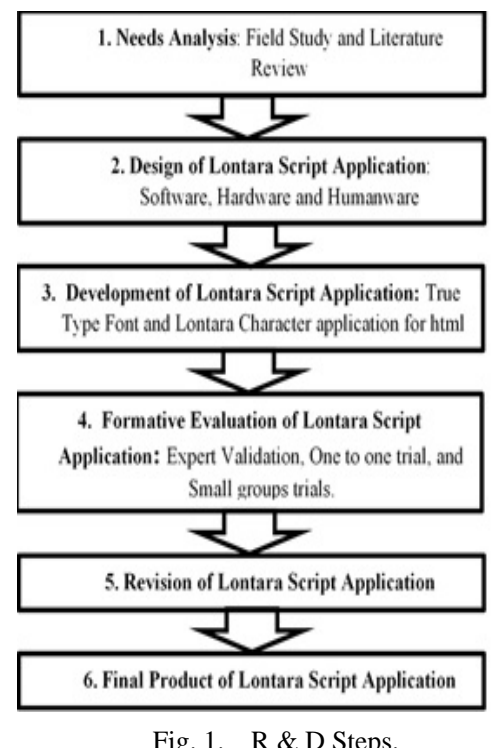

IV. RESULT AND DisCUSSION

This research was conducted for three years, from 2017 to 2019. Application tests were carried out by speakers of Bugis and Makassar languages, two local languages in South Sulawesi, Indonesia. Since the beginning of 2020, this application has been free to download on the Hasanuddin University website, https://web.unhas.ac.id/arab/

Referring to previous research methods, in the first stage, the researchers have conducted a needs analysis and literature review since 2018. This $\mathrm{R}$ and $\mathrm{D}$ research continues previous 
research that has produced a True Type Font (TTF) called Lontara Yusring. The Lontara Yusring is limited to use on Windows Operating Systems only. Along with the times, Lontara Yusring's user community needs a script application that can be used to communicate with popular media, including email, Facebook, and smartphones. The researcher then developed an application to meet the Lontara script user's needs based on this need.

The development of communication technology is the main reason for local language teachers in South Sulawesi to use the latest media to support the learning process. The research team conducted depth interviews in three groups. The first groups are the teacher group in the Tompobulu subdistrict, Gowa Regency. Secondly is the Local Language Teachers Association in Parepare City. Furthermore, the third group is the teachers at the As'adiyah Islamic Boarding School Sengkang, Wajo Regency. Based on this dept interview, the researchers obtained information that they urgently need a local language application to be used in the learning and communication process.

In this in-depth interview, those groups explained that in the learning process, writing a lontara script as a local script was not enough; it had to be supported by technology that could be used to write the lontara script. For writing needs on a Windows-based laptop, Lontara Yusring has fulfilled these needs. However, for general communication purposes, another application is required. Based on this need analysis, the research team plans to develop the Lontara Yusring into an application that can be used on HTML and Android platforms.

To meet the needs mentioned in the first stage, the research team then designed the Lontara application. In this step, the researchers designed a lontara script application model focused on software, hardware, and humanware characteristics. This application model is designed to be integrated with the HTML and Android platforms. However, the Lontara characters' position on the keyboard is maintained according to QWERTY as in Yusring Lontara. Thus, the users of Lontara Yusring will remain familiar with the standard of the Lontara Yusring keyboard.

In the third stage, the lontara application design was developed. The research team agreed to give this application a name with Yusring Keyboard. This naming is intended to establish sustainability between the Lontara Yusring and the Yusring Keyboard Application. Therefore, the Lontara Yusring and Yusring keyboard will be combined in one term, namely the lontara application.

The Lontara Yusring, which is intended to be developed in this research, is as shown in the following Fig. 2.

Formative evaluation is the fourth step. This formative evaluation stage consists of expert validation, one-to-one testing, small group testing, and large group testing. Respondents who participated in this stage filled out an instrument called the Technology Acceptance Model (TAM). This TAM instrument is used to measure the acceptability of a technology product marketed to the public. The TAM instrument is also used to determine the ease with which technology is adopted and used by the community [32]-[36].
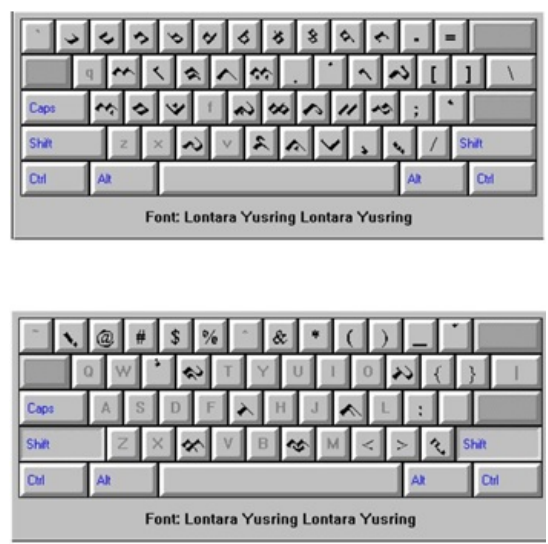

Fig. 2. The TTF Lontara Yusring.

The research team used three TAM instrument constructs: perceived ease of use, perceived usefulness, and attitude toward using. In addition, the team provided instruction that helped the respondent qualify how to interpret the scale (1 being terrible, ten being excellent).

- Perceived Ease of Use

o How would you rate your experience using the lontara application on MS Office?

o How would you rate your experience using the lontara application on the HTML Platform?

o How would you rate your experience using the lontara application on WhatsApp or Telegram for Windows?

- Perceived Usefulness

o This application is quickly used in writing Lontara characters

o Users get the benefits of the Lontara application

o This application is more effectively used in compiling local language learning materials

- Attitude Toward Using

o The position of the QWERTY keyboard is easily recognized on a laptop

o The Lontara Yusring is obtained quickly at the Theme Fonts of MS Office

Expert validation is done by giving this application to developers. The research team included additional requirements that the expert can speak either in Buginese or in Makassarese. This competency is needed because speakers of these two local languages will use the Lontara Yusring and Yusring keyboards. At this stage, two experts used the Lontara Yusring and Yusring Keyboard. One of them is the teaching staff at the Geophysics Study Program, Faculty of Mathematics and Natural Sciences at Hasanuddin University. Another expert is a lecturer at the faculty of computer science at the Indonesian Muslim University. The first expert can speak the Bugis language fluently. The second expert speaks fluently in Makassar. 
The next stage is a one to one test. At this test, the lontara application is given to respondents to use on MS Office, email, Facebook, WhatsApp, and Telegram for Windows. In this stage, the application was addressed to three lecturers within the Faculty of Culture Science at Hasanuddin University and three students in the same environment. In selecting respondents, the research team required that they communicate either in Buginese or Makassarese languages. Also, the respondents had learned to write using the lontara script in elementary or middle school. These respondents were asked to use the lontara application then give a rating according to the TAM instrument.

The small group test is the third test in this fourth stage. Respondents involved in this test must also meet the requirements, namely speaking either Buginese or Makassarese. Also, they are teachers of Bugis or Makassarese languages. Another requirement is to use MS Office, send an email, and write on Facebook, WhatsApp, and Telegram.

In this test, two groups of language teachers were involved. The first group is the Makassar language teaching group. They are twenty teachers and live in the Tompobulu sub-district, Gowa regency. The second group is the Bugis language teaching group in Parepare, where twenty-four teachers participated in this application test. These two groups were chosen because the Lontara script is used by speakers of the Makassar language and Bugis language. However, the level of Makassar language in EGIDS is lower than that of Bugis.

The research team assisted the two groups in installing the Lontara application on their laptops. First, the research team explained how to use the Lontara application in MS Office, email, Facebook, and social media. Then they were asked to use the lontara application to write some local language vocabulary in MS Word. After that, they emailed the vocabulary to one of the teachers. Messages in emails must use the local language in Lontara characters. At the end of the meeting, the two groups were asked to rate the TAM instrument.

The fourth phase in the formative evaluation stage is the large group test. Respondents who participated in this phase had the same requirements as the previous small group test. The difference between small and large groups is only in the number of people involved, and they are not necessarily local language teachers.

The first group is the teachers of the As'adiyah Islamic boarding school in Sengkang, Wajo district. Forty-five teachers participated in this test. The second group is elementary school teachers in the Tompobulu sub-district, Gowa district. Eighty-one teachers were involved in this test.

The application test results in these two groups can be seen in the following Table III.

Revision of the lontara application. Based on the instrument from participants, researchers revised bugs that occur during the stage of formative evaluation. The respondents' suggestions are generally not related to this application, but rather on its socialization to users of this application. Another suggestion is that a guide to installing the Lontara application on the website that provides this application and a guide on using it on MS Office, HTML and Whatsapp for Windows has also been prepared.

Final Product. Thus, this application has been tested in the small and large groups test phase of Formative Evaluation or the fourth stage.

The need to present information in local languages must be well prepared, especially in local languages. The needs of these communities must be aligned with the development of information technology. The digital era has forced humans, including regional language speakers, to interact with other humans through cyberspace. The internet in various electronic mail and social media on Facebook is one of modern humans' most widely used media today.

Although Lontara literature is often marginalized with Latin characters in literacy, it does not mean that the Lontara script should be abandoned. However, some efforts to bring Lontara character to the young generation of the BugisMakassar community must be implemented through information technology in the form of Lontara-based hypertext applications. This Lontara application's readiness is undoubtedly expected to stimulate Lontara users' interest in the HTML platform.

The model of the Lontara application is still referring to the Lontara Yusring. However, this hypertext-based Lontara application has been adapted to the characteristics of the Lontara script itself. Also, the characteristics of software, hardware, and human ware remain to be considered.

TABLE III. LARGE GROUP TEST

\begin{tabular}{|c|c|c|}
\hline TAM Instrument Constructs & $\begin{array}{l}\text { Average } \\
\text { scale of } \\
\text { Gowa group }\end{array}$ & $\begin{array}{l}\text { Average } \\
\text { scale of } \\
\text { Wajo group }\end{array}$ \\
\hline \multicolumn{3}{|l|}{ a. Perceived Ease of Use } \\
\hline $\begin{array}{l}\text { How would you rate your experience using } \\
\text { lontara application on MS Office? }\end{array}$ & 8 & 8 \\
\hline $\begin{array}{l}\text { How would you rate your experience } \\
\text { using lontara application on HTML } \\
\text { Platform? }\end{array}$ & 10 & 9 \\
\hline $\begin{array}{l}\text { How would you rate your experience } \\
\text { using lontara application on WhatsApp or } \\
\text { Telegram for Windows? }\end{array}$ & 9 & 10 \\
\hline \multicolumn{3}{|l|}{ b. Perceived Usefulness } \\
\hline $\begin{array}{l}\text { This application is quickly used in writing } \\
\text { Lontara characters }\end{array}$ & 10 & 9 \\
\hline $\begin{array}{l}\text { Users get the benefits of the Lontara } \\
\text { application }\end{array}$ & 8 & 9 \\
\hline $\begin{array}{l}\text { This application is more effectively used } \\
\text { in compiling local language learning } \\
\text { materials }\end{array}$ & 9 & 8 \\
\hline \multicolumn{3}{|l|}{ c. Attitude Toward Using } \\
\hline $\begin{array}{l}\text { The position of the QWERTY keyboard is } \\
\text { easily recognized on a laptop }\end{array}$ & 8 & 10 \\
\hline $\begin{array}{l}\text { TTF Lontara Yusring is obtained quickly } \\
\text { at the Theme Fonts of MS Office }\end{array}$ & 10 & 9 \\
\hline AVERAGE & 9 & 9 \\
\hline
\end{tabular}


The Lontara Yusring is still paying attention to the QWERTY keyboard model. However, this Lontara Yusring can only run on a Windows-based operating system. In the browser application, some treatments on settings need to be done. The treatment is required after the hypertext-based Lontara Yusring is installed. This need should be done because this Lontara letter's application does not include the Windows operating system's default fonts. Thus, a personal computer or laptop that has not been installed with a Lontara application cannot recognize the character.

Via email, Bugis-Makassar speakers can send messages using this research product. Indeed, to read these lontara characters on personal computers and laptops, the user needs to install the lontara application since the Lontara Yusring is not the official default of the Windows operating system. Therefore, lontara script users must install this application. So, both the message's sender and the lontara script's message must first install the lontara application. If it is not installed, lontara characters will appear on the personal computer screen or laptop users in the form of boxes.

Users of the lontara application can communicate either when sending messages via email or Facebook or creating interactive applications. Of course, it is expected that the younger generation of Bugis-Makassar knows and utilizes this lontara application. Using the lontara application, both oral and written, can be maintained in the writer's view. Thus, on the other hand, there is a local language sustainability action in place in this country expressing their ideas using the local language. Sometimes past romanticism has been just right and appropriate if it is expressed in the local language. Of course, local characters such as lontara characters should be able to support the speakers' wishes. In other words, the local script's character should be integrated with the development of information technology.

The same procedure can be done when the lontara application will be used on Facebook or social media. For example, an essential step for Facebook users (Facebooker) is to change the keyboard system from a standard keyboard to a lontara keyboard. The trick was relatively easy, that is, by choosing the lontara keyboard. In other words, this stage is the same if the user of the lontara application will send a message via email. An example of the lontara script on Facebook social media can be seen in the following picture.

The users of the lontara application can also take advantage of creating interactive material questions. Various applications can make this type of interactive exercise or interactive questions, including Hot Potatoes [37]. Hot Potatoes [38] is one of the most popular closed-circuit maker applications. This app is used to create multiple choice questions, match, crosswords, short stuffing, and composing sentences-result or output of this application in HTML-based file. The language characters that can be used in this Hot Potatoes application are all characters that are the default Windows operating system. Thus, the lontara application must be installed first for a personal computer or laptop user lontara application.

Lontara Application can also be used on other social media, for example, Whatsapp and Telegram. In this case, the lontara application must be used on the keyboard of a laptop or personal computer (input) and not on a smartphone. However, Whatsapp or Telegram, where the lontara application is used, can still be seen (output). For example, the lontara application, which is inputted on Whatsapp and Telegram laptop but seen on mobile, can be seen in the following Fig. 3:

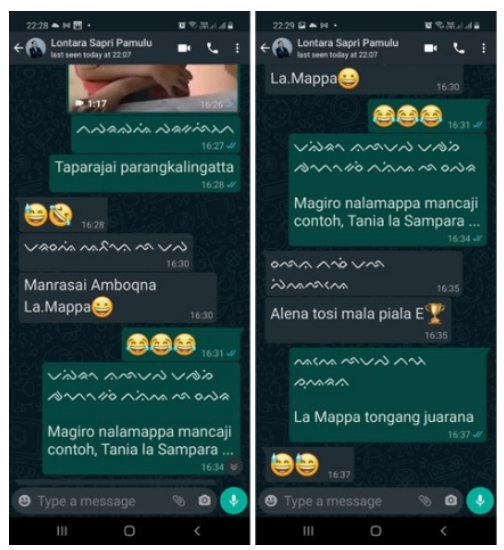

Fig. 3. Lontara Yusring on Whatsapp.

Although the Lontara application can be utilized in Microsoft Office, the HTML platform can be seen on android. It does not mean maintaining the local language ends at this stage. The central and local government policies are essential to maintain regional languages. Without this policy, the local language observers, including language researchers, will face many potential challenges. For example, government policy requires every elementary and secondary level to continue studying their local languages, which is very important. However, the policy is not enough. The government of society must create space and a stage to display regional languages and literature. Government policy can be implemented by preparing columns in local newspapers once or twice a week. Publication of language and literature and local wisdom written in the local language familiarize the speakers of local languages accustomed and aware of the region's local wealth and wisdom.

To sustain the local language is a joint effort of various nation components. The government has a role in making policies and preparing budgets to support the policy. On the other hand, educators should teach the important role of regional and literary languages in life, especially in primary and secondary schools. Do not miss the local language users to use the local language in everyday conversations, especially non-formal events. Communication in the local language is not intended to undermine the national language's function since Indonesian can be found in every segment of communication, both formal and informal. This condition makes the Indonesian nation, directly and indirectly, use the Indonesian language in both oral and written forms.

This condition is somewhat different from the existence of local languages. Besides, local language characters should be brought closer to the development of technology. Space and stage use must also be considered. The writer expects that the lontara application with hypertext-based can be utilized by both tribes Bugis and Makassar, in expressing their ideas using the local language. Of course, local characters such as the 
lontara application should support the speakers' wishes. In other words, the local script's character should be integrated with the development of information technology.

With this lontara application, the researchers hope that Bugis-Makassar speakers and other Lontara script users can communicate using this application, either when sending messages via email or Facebook or creating interactive applications. Of course, it is expected that the younger generation of Bugis-Makassar knows and utilizes this Lontara application. Only by using the Lontara script, both oral and written can be maintained in the writers' view. Thus, on the other hand, there is a local language sustainability action in place in this country expressing their ideas using the local language.

\section{CONCLUSION}

The lontara application model has been created. This application has been tested on a one-to-one test, small groups test, and large groups test. The participants from groups were very enthusiastic and were happy with this lontara application. This application helps them in teaching the local language. Also, they find it easy to prepare lontara script learning materials through this application.

The next step is launching this application for lontara users. The researchers recommend that the government issue a policy to implement learning lontara manuscripts in elementary to high school officially. Policies in the form of regulations will be a guide for local language teachers. This policy can be called a real, maintaining the local wisdom of South Sulawesi. Optimizing the use of this application is expected to be one of the concrete actions to maintain the local language in South Sulawesi.

\section{ACKNOWLEDGMENT}

This study is supported by the Hasanuddin University research grant scheme of BMIS number 2018.

\section{REFERENCES}

[1] BPS, "Kewarganegaraan, Suku Bangsa, Agama, dan Bahasa Sehari-hari Penduduk Indonesia; Hasil Sensus Penduduk 2010,” Badan Statistik Indonesia, 2010.2 [Online]. Available: https://www.bps.go.id/publication/2012/05/23/55eca38b7fe0830834605 b35/kewarganegaraan-suku-bangsa-agama-dan-bahasa-sehari-haripenduduk-indonesia.html. [Accessed: 28-Oct-2020].

[2] C. D. F. Eberhard, David M., Gary F. Simons, "Indonesia," Dallas, Texas: SIL International, 2020. [Online]. Available: https://www.ethnologue.com/country/ID. [Accessed: 24-Dec-2020].

[3] A. A. Ghani, The Teaching of Indigenous Orang Asli Language in Peninsular Malaysia, vol. 208, no. Icllic 2014. Elsevier B.V., 2015.

[4] G. F. Simons, S. I. L. International, M. Paul, and L. Sil, "The world ' s languages in crisis : A 20-year update A 20-year update," 26th Linguist. Symp. Lang. Death, Endangerment, Doc. Revital., no. June, 2012.

[5] UNESCO, "Towards UNESCO guidelines on Language Policies: a Tool for Language Assessment and Planning,” UNESCO, 2012. [Online]. Available: http://www.unesco.org/new/en/communication-andinformation/resources/news-and-in-focusarticles/allnews/news/towards_unesco_guidelines_on_language_policies -1/. [Accessed: 28-Oct-2020].

[6] M. David and G. F. Simons, "Makasar in the Language Cloud," 2020. [Online]. Available: https://www.ethnologue.com/cloud/mak. [Accessed: 23-Dec-2020].

[7] B. Marshall, "Local Language Vitality in Indonesia; Assessing and Intervening using Makassarese as a case study,” 2018.
[8] K. Gao, "Assessing the Linguistic Vitality of Miqie: An Endangered Ngwi (Loloish) Language of Yunnan, China,” vol. 9, pp. 164-191, 2015.

[9] D. Gumina, "Language power and hierarchy: Multilingual education in China,” Int. Multiling. Res. J., 2018.

[10] G. M. H. Kim, "Practicing Multilingual Identities: Online Interactions in a Korean Dramas Forum,” Int. Multiling. Res. J., 2016.

[11] G. F. Simons and M. P. Lewis, "The world's languages in crisis,” no. January 2013, pp. 3-20, 2013.

[12] G. F. Simons, “Two centuries of spreading language loss," Proc. Linguist. Soc. Am., vol. 4, no. 1, p. 27, 2019.

[13] C. D. F. Eberhard, David M., Gary F. Simons, "How many languages are there in the world?," Dallas, Texas: SIL International, 2020. [Online]. Available: https://www.ethnologue.com/guides/how-many-languages. [Accessed: 24-Dec-2020].

[14] M. G. Delavan, V. E. Valdez, and J. A. Freire, "Language as Whose Resource?: When Global Economics Usurp the Local Equity Potentials of Dual Language Education,” Int. Multiling. Res. J., 2017.

[15] M. Brenzinger, A. Yamamoto, and N. Aikawa, "Language vitality and endangerment,”/ich/doc/src/00120-en. pdf., 2003.

[16] M. Brenzinger, "Language Maintenance and Shift," in Encyclopedia of Language \& Linguistics, 2006.

[17] D. I. Odugu, "Antinomies of Ideologies and Situationality of Education Language Politics in Multilingual Contexts,” Int. Multiling. Res. J., 2015.

[18] I. C. Pérez, "Indigenous Languages, Identity and Legal Framework in Latin America: An Ecolinguistic Approach1,” Procedia - Soc. Behav. Sci., 2015.

[19] S. W. Y. Lo-Philip, "Towards a theoretical framework of heritage language literacy and identity processes,” Linguist. Educ., 2010.

[20] D. Cunliffe, "The market for Welsh language mobile applications - A developers' perspective,” Telemat. Informatics, 2019.

[21] G. Valdés, "Latin@s and the Intergenerational Continuity of Spanish: The Challenges of Curricularizing Language," Int. Multiling. Res. J., 2015.

[22] A. M. Nonaka, "Estimating size, scope, and membership of the speech/sign communities of undocumented indigenous/village sign languages: The Ban Khor case study,” Lang. Commun., 2009.

[23] W. K. Sisamouth and S. C. Lah, Attitudes towards Thai, Patani Malay, and English of Thai Undergraduates: A Case Study at Prince of Songkla University Pattani Campus, Thailand, vol. 208, no. Icllic 2014. Elsevier B.V., 2015.

[24] D. Naisbitt and J. Naisbitt, Mastering Megatrends:\&nbsp;Understanding and Leveraging the Evolving New World. 2019.

[25] Y. S. Baso, "Model Aplikasi Aksara Lontara Berbasis HTML sebagai Salah Satu Solusi Pemertahanan Bahasa Daerah,” J. KATA, vol. 2, no. 1-12, 2018.

[26] Y. S. Baso, Model Inovatif Pemertahanan Bahasa Daerah, 1st ed. Makassar: Pusat Kajian Media, Sumber Belajar dan E-Learning LKPP UNHAS, 2017.

[27] Wikipedia, “Abu al-Aswad al-Du’ali,” 2020. [Online]. Available: https://en.wikipedia.org/wiki/Abu_al-Aswad_al-Du\%27ali. [Accessed: 24-Dec-2020].

[28] H. Aliane, Z. Alimazighi, and M. A. Cherif, "Al-Khalil: The Arabic linguistic ontology project," in Proceedings of the 7th International Conference on Language Resources and Evaluation, LREC 2010, 2010.

[29] N. Bennett, W. R. Borg, and M. D. Gall, "Educational Research: An Introduction,” Br. J. Educ. Stud., 1984.

[30] M. D. Gall, J. P. Gall, and W. R. Borg, "Educational Research: An Introduction, 8th Edition,” Educ. An Introd., 2006.

[31] W. Dick and L. Carey, The systematic design of instruction. 6th. 2015.

[32] G. Khorasani and L. Zeyun, "Implementation of Technology Acceptance Model (TAM) in Business Research on Web Based Learning System 113,” Int. J. Innov. Technol. Explor. Eng., 2014.

[33] D. Persico, S. Manca, and F. Pozzi, “Adapting the technology acceptance model to evaluate the innovative potential of e-learning systems,” Comput. Human Behav., 2014. 
[34] V. Venkatesh and H. Bala, “Technology acceptance model 3 and a research agenda on interventions,” Decis. Sci., 2008.

[35] M. Chuttur, “Overview of the Technology Acceptance Model: Origins , Developments and Future Directions,” Sprouts Work. Pap. Inf. Syst., 2009.

[36] A. U. Jan and V. Contreras, "Technology acceptance model for the use of information technology in universities," Comput. Human Behav., 2011.
[37] University of Victoria, “Hot Potatoes," 2020. [Online]. Available: https://hotpot.uvic.ca/. [Accessed: 24-Dec-2020].

[38] Y. S. Baso, Aplikasi pembuat soal-soal interaktif pembelajaran bahasa, 1st ed. Makassar: Pusat Kajian Media dan Sumber Belajar LPMPP Universitas Hasanuddin, 2017. 